Article

\title{
Quantitative Effect of Zr Content on the Structure and Water-Gas Shift Reaction Activities of Gold Supported on Ceria-Zirconia
}

\author{
Li Song ${ }^{\mathbb{D}}$, Longfeng Zhu ${ }^{(\mathbb{D})}$ and Lei $\mathrm{Li}^{*} \mathbb{D}$ \\ College of Biological, Chemical Sciences and Engineering, Jiaxing University, Jiaxing 314001, China; \\ songli@mail.zjxu.edu.cn (L.S.); zhulf1988@mail.zjxu.edu.cn (L.Z.) \\ * Correspondence: leili@mail.zjxu.edu.cn; Tel.: +86-573-83643852
}

Received: 5 June 2018; Accepted: 23 June 2018; Published: 26 June 2018

\begin{abstract}
Effect of $\mathrm{Zr}$ content on the structure and water-gas shift reaction catalytic activities of $\mathrm{Au}-\mathrm{CeO}_{2}-\mathrm{ZrO}_{2}$ catalysts were quantitatively analyzed in detail. For the low $\mathrm{ZrO}_{2}$ content (0-15 wt. \%), the $\mathrm{Ce}-\mathrm{Zr}-\mathrm{O}$ solid solutions were formed through the substitutional incorporation of $\mathrm{Zr}$ cations into $\mathrm{CeO}_{2}$ lattice, resulting in the contraction of cell parameters $a$ and $d$-spacing (i.e., lattice distortion) and the increase of microstrain and oxygen vacancies. Quantitatively, the enhanced WGS activities have good linear correlation with the cell parameters $a$, microstrain, Raman shift and oxygen vacancies. Whereas, for the rich-zirconia (45 wt. \%) sample, Au-CeZr-45 has some isolated $t-\mathrm{ZrO}_{2}$ and fluorite $\mathrm{CeO}_{2}$ instead of solid solution. The isolated $t-\mathrm{ZrO}_{2}$ crystallites block the contact between $\mathrm{Au}$ and $\mathrm{CeO}_{2}$, resulting in the agglomeration of gold clusters and, as a consequence, poor WGS activity of Au-CeZr-45 catalyst.
\end{abstract}

Keywords: gas shift; gold catalyst; $\mathrm{CeO}_{2} ; \mathrm{ZrO}_{2}$

\section{Introduction}

The water-gas shift (WGS) reaction ( $\mathrm{CO}+\mathrm{H}_{2} \mathrm{O} \leftrightarrow \mathrm{CO}_{2}+\mathrm{H}_{2}$ ) has represented a paramount step in the industrial production of hydrogen. Nevertheless, the traditional WGS catalysts (such as $\mathrm{Cu}-\mathrm{Zn}-\mathrm{Al}, \mathrm{Fe}-\mathrm{Cr}$ and $\mathrm{Co}-\mathrm{Mo}$ ) often require complicated prereduction and/or prevulcanization or are possibly pyrophoric. Accordingly, some new efficient WGS catalysts, such as supported catalysts, are continuously pursued. For instance, both precious metals (Pt, $\mathrm{Au}, \mathrm{Rh}, \mathrm{Ir}, \mathrm{Pd}, \mathrm{Ru}$, etc.) [1,2] and non-precious metals $\left(\mathrm{Ni}\right.$ and $\mathrm{Cu}$ ) [3] were supported on various oxides, such as $\mathrm{TiO}_{2}$ [4-8], $\mathrm{CeO}_{2}$ [9-12], $\mathrm{ZrO}_{2}$ [13-17], $\mathrm{Mo}_{2} \mathrm{C}[18]$ and $\mathrm{FeO}_{\mathrm{x}}[19,20]$. Hereinto, due to the high activity and selectivity of dispersed $\mathrm{Au}$ [1], gold catalysts have been considered among the most promising WGS catalysts. Meanwhile, for the supports, $\mathrm{CeO}_{2}$ has been paid considerable attention, due to the high oxygen storage capacity (OSC) of ceria, associated with its rich oxygen vacancies, the character of strong interaction with active metal and the easy change between $\mathrm{Ce}^{3+}$ and $\mathrm{Ce}^{4+}$ [9-12]. Thus, $\mathrm{Au}-\mathrm{CeO}_{2}$ should be potential catalysts to deliver high WGS activities.

The catalytic activity of $\mathrm{CeO}_{2}$-based catalysts are significantly enhanced by the presence of a small amount of transition metal due to the synergistic effect among multiple components compared with single-component supports. For example, the mixed oxides, like $\mathrm{CeO}_{2}-\mathrm{TiO}_{2}$ [21], $\mathrm{CeO}_{2}-\mathrm{ZrO}_{2}$ [22-26], $\mathrm{CeO}_{2}-\mathrm{La}_{2} \mathrm{O}_{3}$ [27] and $\mathrm{CeO}_{2}-\mathrm{Co}_{3} \mathrm{O}_{4}$ [28], were usually paid considerable attention. Hereinto, the $\mathrm{Ce}-\mathrm{Zr}-\mathrm{O}$ solid solution were easily approached by the introduction of $\mathrm{Zr}$. Accordingly, addition of $\mathrm{Zr}$ to $\mathrm{CeO}_{2}$ has been reported to improve the oxygen storage capacity of ceria, which is paramount for the above WGS, CO oxidation [29] and steam reforming of methanol [30]. Nevertheless, the amount of incorporated $\mathrm{Zr}$ in the $\mathrm{Ce}-\mathrm{Zr}-\mathrm{O}$ solid solution should have the maximum. Furthermore, the effect of $\mathrm{Zr}$ 
content on the structure and water-gas shift reaction catalytic activities of $\mathrm{Au}-\mathrm{CeO}_{2}-\mathrm{ZrO}$ catalysts should be quantitatively analyzed in detail, to our best knowledge, which has been rarely reported.

In the present work, quantitative effect of $\mathrm{Zr}$ content on the structure and water-gas shift reaction catalytic activities of $\mathrm{Au}-\mathrm{CeO}_{2}-\mathrm{ZrO}_{2}$ catalysts were investigated in detail. The results indicate that the enhanced WGS activities correlate well in a linear fashion with the cell parameters $a$, microstrain, Raman shift and oxygen vacancies.

\section{Experimental}

\subsection{Catalyst Preparation}

Firstly, a series of $\mathrm{CeO}_{2}$ doped with various zirconia content (i.e., 0, 3, 5, 15, 45 wt. \%, calculated as $\mathrm{ZrO}_{2}$ ) were prepared by co-precipitation method and used as supports. In brief, the mixed aqueous solution of $\mathrm{Ce}\left(\mathrm{NO}_{3}\right)_{3} \cdot 6 \mathrm{H}_{2} \mathrm{O}(1 \mathrm{~mol} / \mathrm{L})$ and $\mathrm{ZrOCl}_{2} \cdot 8 \mathrm{H}_{2} \mathrm{O}$ with desired $\mathrm{Zr}$ content was precipitated by parallel addition of $3 \mathrm{~mol} / \mathrm{L} \mathrm{NH}_{3} \cdot \mathrm{H}_{2} \mathrm{O}$ solution with mechanical stirring at $60( \pm 3){ }^{\circ} \mathrm{C}$, keeping the $\mathrm{pH}$ at 8-9 and aging the resulting precipitate for $1 \mathrm{~h}$. After that, the precipitate was centrifuged and washed several times with distilled water until there were no residual $\mathrm{Cl}^{-}$ions in the supernatant, which were detected by an aqueous solution of $\mathrm{AgNO}_{3}(0.1 \mathrm{~mol} / \mathrm{L})$. The precipitate was dried overnight at $110^{\circ} \mathrm{C}$ and calcined in static air at $300{ }^{\circ} \mathrm{C}$ for $2 \mathrm{~h}$.

Then, the fixed content ( $3 \mathrm{wt}$. \%) of gold was loaded on the above as-synthesized support by deposition-precipitation. The detailed procedure is described as follows. The above as-synthesized $\mathrm{CeO}_{2}-\mathrm{ZrO}_{2}$ support $(0.7 \mathrm{~g})$ was dispersed in $100 \mathrm{~mL}$ of deionized water by sonication for $10 \mathrm{~min}$. The $\mathrm{HAuCl}_{4}(0.0025 \mathrm{~mol} / \mathrm{L}, 44 \mathrm{~mL})$ and a certain amount of $\mathrm{NH}_{3} \cdot \mathrm{H}_{2} \mathrm{O}(0.05 \mathrm{~mol} / \mathrm{L})$ solution were simultaneously added into the above suspension, and the $\mathrm{pH}$ value and the temperature of the solution were kept at $9-10$ and $60^{\circ} \mathrm{C}$, respectively. After aging of $4 \mathrm{~h}$, the samples were carefully washed like the supports, and then also dried overnight at $110^{\circ} \mathrm{C}$ and calcined in air at $300{ }^{\circ} \mathrm{C}$ for $4 \mathrm{~h}$. Depending on the different zirconia content, the final samples were denoted as $\mathrm{Au}-\mathrm{Ce}, \mathrm{Au}-\mathrm{CeZr}-3$, $\mathrm{Au}-\mathrm{CeZr}-5, \mathrm{Au}-\mathrm{CeZr}-15$ and Au-CeZr-45, respectively.

\subsection{Catalytic Test}

The catalytic activity measurements of all samples towards the WGS reaction were carried out in a commercial fixed-bed reactor (CO-CMAT9002, HD Co. Ltd., Beijing, China) at atmospheric pressure. A stainless-steel tube with an inner diameter of $9 \mathrm{~mm}$ was chosen as the reactor. The catalysts were firstly sieved to obtain granules, then $0.7 \mathrm{~g}$ of catalyst granules between 20 mesh and 40 mesh were placed between two quartz wool layers in the reactor. For the measurement of reaction temperature, two thermocouples were inserted into the reactor wall and the catalyst bed, respectively. The experiment was directly performed under feed gas $\left(10 \%\right.$ CO balance in $\left.\mathrm{N}_{2}\right)$ with the flow rate of $85 \mathrm{~mL} / \mathrm{min}$ at standard temperature and pressure (STP) without any pre-reduction. Water was injected into the flowing gas stream by calibrated syringe pump and vaporized in the vaporizer $\left(110^{\circ} \mathrm{C}\right)$ before entering the reactor. The ratio of vapor to feed gas was maintained at 1:1. A condenser was installed after the reactor to remove water. The outflow was analyzed using an on-line gas chromatograph (Shimadzu GC-8A) equipped with a thermal conductivity detector. The CO conversion was calculated as follows: $\mathrm{X}_{\mathrm{CO}}(\%)=\left(1-\mathrm{V}_{\mathrm{CO}}^{\prime} / \mathrm{V}_{\mathrm{CO}}\right) \times 100 \% /\left(1+\mathrm{V}_{\mathrm{CO}}^{\prime}\right)[8,9]$, where $\mathrm{V}_{\mathrm{CO}}$ and $\mathrm{V}_{\mathrm{CO}}^{\prime}$ are the inlet and outlet content of $\mathrm{CO}$ of dry gas due to condensation, respectively.

\subsection{Characterizations}

X-ray powder diffraction (XRD) patterns of the samples were obtained on a Bruke D8 Advance X-ray diffractometer, using $\mathrm{Cu} \mathrm{K} \alpha_{1}$ radiation $\left(40 \mathrm{~mA}, 40 \mathrm{kV}\right.$ ) over the range $2 \theta=20^{\circ}-70^{\circ}$ (a scan rate of $2^{\circ} / \mathrm{min}$ ). For Rietveld analysis, the XRD pattern of standard reference material (NIST 640A silicon), which is a material with no microstrain nor size broadening, was measured from $10^{\circ}$ to $140^{\circ}$ on the same instrument with the same experimental parameters. The patterns of the standard and 
experimental samples were fitted with a pseudo-Voigt function (PVF), which were carried out with $X^{\prime}$ pert highscore plus software. High resolution transmission electron microscopy (HRTEM) analysis was performed using a JEOL-2100 microscope. The powered samples were ultrasonically dispersed in ethanol and the obtained suspensions were deposited on a copper grid, coated with a porous carbon film. Raman spectra were collected at room temperature on a Renishaw Invia Plus instrument using a semiconductor laser as an illumination source $(532 \mathrm{~nm})$. The actual Au loading in each catalyst was measured by ion coupled plasma-atomic emission spectroscopy (ICP-OES) using a Varian 710-ES analyzer (Varian, Englewood, NJ, USA).

\section{Results and Discussions}

The WGS catalytic activity of the $\mathrm{Au}-\mathrm{CeO}_{2}-\mathrm{ZrO}_{2}$ catalysts with various zirconia content are presented in Figure 1. Compared with Au-Ce catalyst, the trifle addition of zirconia (Au-CeZr-3) did not significantly influence the WGS catalytic activity. With the increase of zirconia content (5 wt. \%-15 wt. \%), the WGS activities gradually increased. For instance, the CO conversion of Au-CeZr-15 catalyst arrived at the maximum, and noticeably increased by $23 \%$ (i.e., from $40.2 \%$ to $49.5 \%$ at $200{ }^{\circ} \mathrm{C}$ ) compared with Au-Ce catalyst. However, rich-zirconia Au-CeZr-45 catalyst showed poor activity. The WGS reaction activity of the samples will be related to their structural properties.

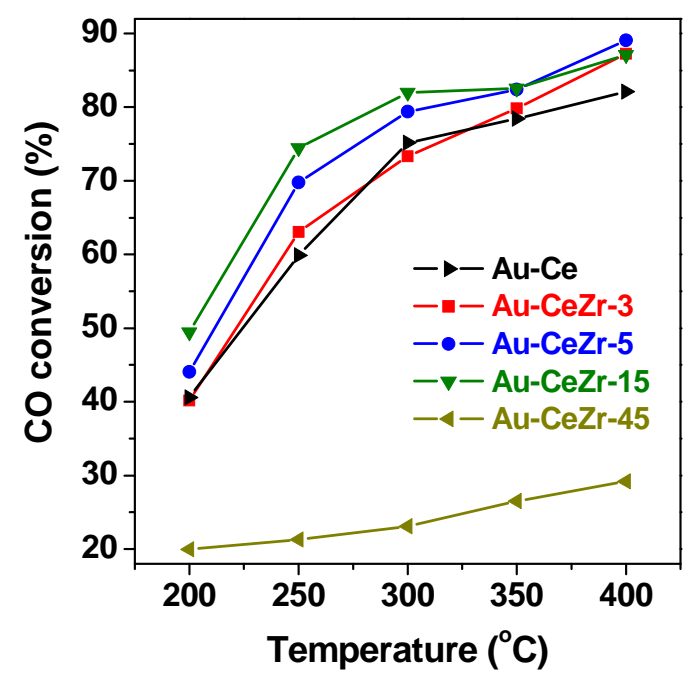

Figure 1. Catalytic activity of various $\mathrm{Au}-\mathrm{CeO}_{2}-\mathrm{ZrO}_{2}$ catalysts.

As shown in Figure 2a, the diffraction peaks of the fluorite structure of ceria (JCPDS: 43-1002) were observed in all samples. With an increase of $\mathrm{Zr}$ content, the diffraction peaks of $\mathrm{CeO}_{2}$ gradually weaken and broaden. Correspondingly, the crystal sizes of $\mathrm{CeO}_{2}$ were calculated from the Rietveld analysis of XRD patterns and gradually decreased, as listed in Table 1. In addition, the diffraction peaks of rich-zirconia Au-CeZr-45 catalyst obviously shift to higher diffraction angles. This significant upshift might be ascribed to the formation of $\mathrm{Ce}-\mathrm{Zr}-\mathrm{O}$ solid solution through the substitutional incorporation of $\mathrm{Zr}$ cations into $\mathrm{CeO}_{2}$ lattice. For this reason, the cell parameters $(a)$ and lattice spacing ( $d$-spacing) were calculated from the Rietveld analysis of XRD patterns, as presented in Table 1. It is found that both cell parameters $a$ and $d$-spacing gradually decreased with the increase of $\mathrm{Zr}$ content. The above lattice contraction might be ascribed to the substitutional incorporation of $\mathrm{Zr}$ cations into $\mathrm{CeO}_{2}$ lattice, because the radius of $\mathrm{Zr}^{4+}(0.084 \mathrm{~nm})$ is smaller than that of the $\mathrm{Ce}^{4+}(0.092 \mathrm{~nm})$. Thus, some Ce- $\mathrm{Zr}-\mathrm{O}$ solid solutions were formed. 

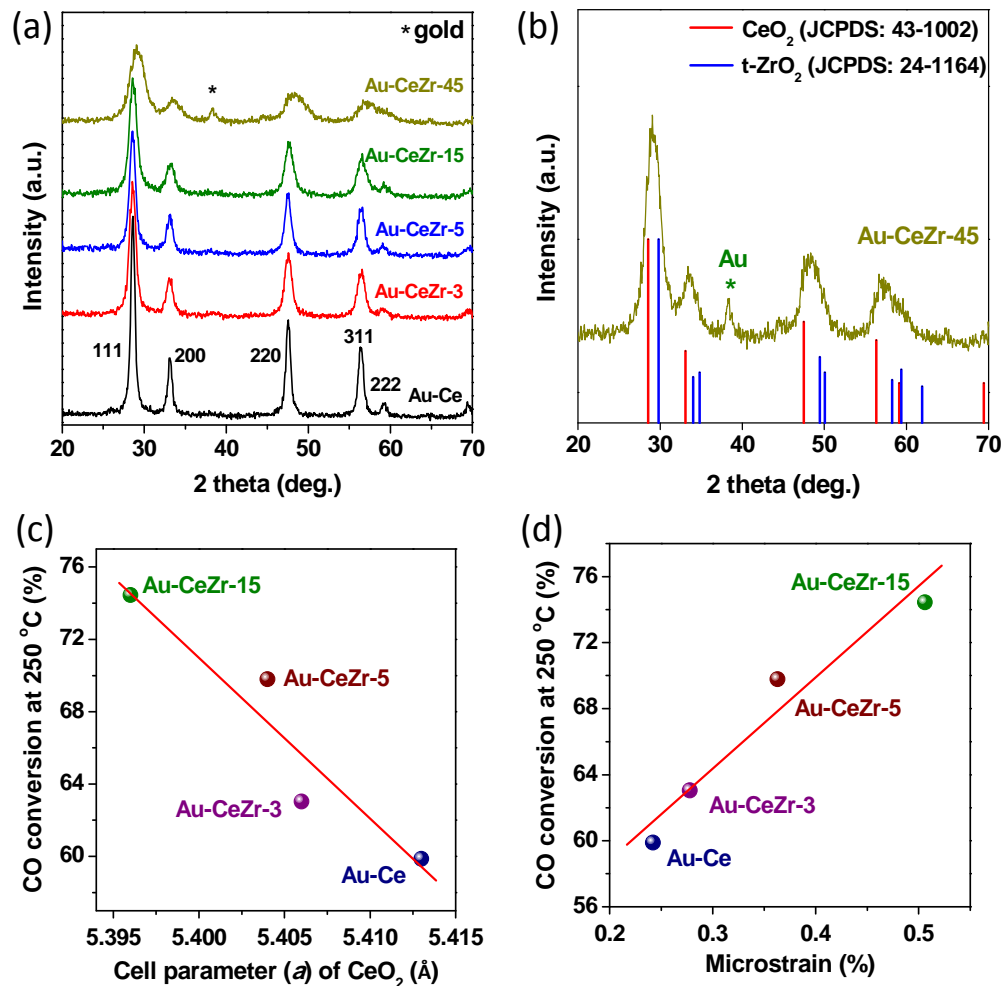

Figure 2. X-ray diffraction patterns of various $\mathrm{Au}-\mathrm{CeO}_{2}-\mathrm{ZrO}_{2}$ catalysts $(\mathbf{a}, \mathbf{b}) ; \mathrm{CO}$ conversion at $250{ }^{\circ} \mathrm{C}$ (\%) vs. cell parameter (a) of $\mathrm{CeO}_{2}(\AA)$ (c) and microstrain (\%) (d).

Table 1. Physical properties and microstructural parameters of Au/ceria-zirconia catalysts.

\begin{tabular}{|c|c|c|c|c|}
\hline Catalysts & Au Content (\%) & $a$ of $\mathrm{CeO}_{2}(\AA)$ & $d$-Spacing of $\mathrm{CeO}_{2}(111)(\mathrm{nm})$ & Crystal Size of $\mathrm{CeO}_{2}(\mathrm{~nm})$ \\
\hline $\mathrm{Au}-\mathrm{Ce}$ & 3.34 & 5.413 & 0.3125 & 17.2 \\
\hline $\mathrm{Au}-\mathrm{CeZr}-3$ & 3.32 & 5.406 & 0.3121 & 11.3 \\
\hline $\mathrm{Au}-\mathrm{CeZr}-5$ & 3.25 & 5.404 & 0.3120 & 10.3 \\
\hline $\mathrm{Au}-\mathrm{CeZr}-15$ & 3.26 & 5.396 & 0.3115 & 8.8 \\
\hline $\mathrm{Au}-\mathrm{CeZr}-45$ & 3.35 & 5.380 & 0.3106 & 5.5 \\
\hline
\end{tabular}

More impressively, as shown in Figure 2c, there is a softer linear relationship between the cell parameters $a$ and $\mathrm{CO}$ conversion at $250{ }^{\circ} \mathrm{C}$ in the range of $0-15 \mathrm{wt}$. \% of $\mathrm{Zr}$ content, illustrating that the Ce-Zr-O solid solution facilitated the improvement of WGS activities. However, the rich-zirconia $\mathrm{Au}-\mathrm{CeZr}-45$ catalyst present the poorest WGS activity, might be attributed to the overloading of $\mathrm{Zr}$ content. Accordingly, the limited solubility of $\mathrm{Ce}-\mathrm{Zr}-\mathrm{O}$ solid solution was calculated by the empirical formula described as follows [31]:

$$
a_{C e}=0.5413+\sum_{k}\left(0.022 \Delta r_{k}+0.00015 \Delta z_{k}\right) m_{k}
$$

where $a$ (in nanometers) is the lattice parameter of the fluorite structured solid solution at room temperature, $\Delta r_{k}$ is the difference in ionic radius $\left(r_{Z r}-r_{C e}\right), \Delta z_{k}$ is the valence difference between $\mathrm{Ce}^{4+}$ and $\mathrm{Zr}^{4+}$, and $m_{k}$ is the mole percent of the $\mathrm{Zr}$ dopant. Based on the experimental lattice parameter $a_{C e}$ listed in Table 1, the theoretical value of $m_{Z r}$ in rich-zirconia Au-CeZr-45 catalyst is calculated to 18.8 at. \%. which is lower than the experimental value of 53 at. \% (i.e., 45 wt. $\%$ of $\mathrm{ZrO}_{2}$ ). It means that there is about 34.2 at. $\% \mathrm{ZrO}_{2}$ exist as isolated tetragonal zirconia $\left(t-\mathrm{ZrO}_{2}\right.$, as shown in Figure $\left.2 b\right)$ in $\mathrm{Au}-\mathrm{CeZr}-45$ catalyst, which will be further confirmed from the next HRTEM and Raman analyses.

Furthermore, all the catalysts have almost identical Au loading (Table 1), suggesting that the loading of gold was not influenced by the changing of zirconium content in ceria-zirconia support. 
However, isolated $t-\mathrm{ZrO}_{2}$ microcrystallite and $\mathrm{Ce}-\mathrm{Zr}-\mathrm{O}$ solid solution presented the different effects on particle size of Au clusters. As shown in Figure 2a, no peaks related to any gold species $\left(2 \theta=38.2^{\circ}\right)$ are discernible in the samples with less amount $(0 \mathrm{wt} . \%-15 \mathrm{wt}$. \%) of zirconia, while the obvious diffraction peak of Au clusters was observed in rich-zirconia Au-CeZr- 45 catalyst. The results indicate that the agglomeration of gold clusters that has occurred might be due to that the isolated $\mathrm{ZrO}_{2}$ crystallites block the contact between $\mathrm{Au}$ and ceria. In other words, the excessive isolated $\mathrm{ZrO}_{2}$ crystallites result in the sintering of Au particles, as reported in the literature [30]. Additionally, HRTEM results also indicate that the Au-CeZr-15 catalyst (around 5-10 nm, Figure 3a) has smaller particle size of $\mathrm{Au}$ compared with Au-CeZr-45 catalyst (around 20-50 nm, Figure 3c). This sintering of Au particles should be responsible for the poor WGS activity of Au-CeZr-45 catalyst. Therefore, Ce-Zr-O solid solution in the low $\mathrm{Zr}$ content of catalysts facilitated the dispersion of Au particles and improvement of WGS activities, whereas the excessive isolated $\mathrm{ZrO}_{2}$ crystallites result in the sintering of $\mathrm{Au}$ particles and poor WGS activity.
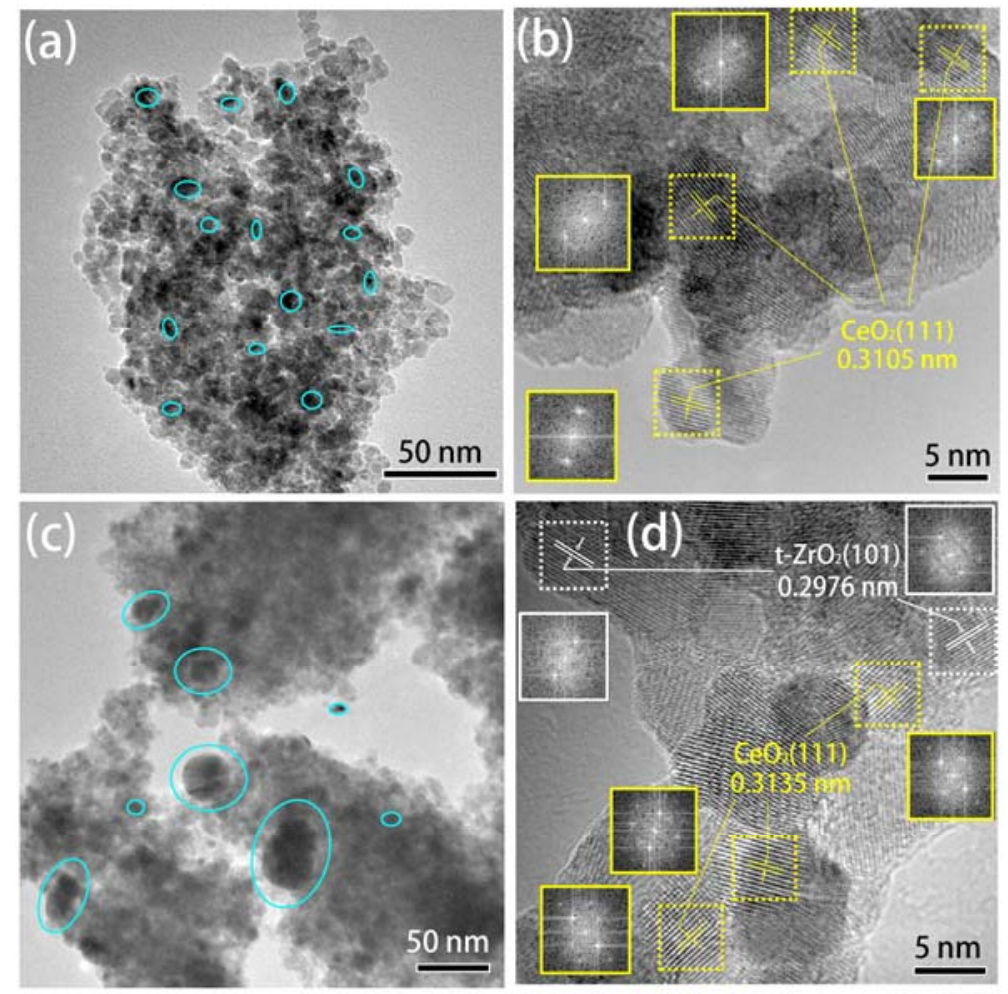

Figure 3. TEM image of the Au-CeZr-15 (a,b) and Au-CeZr-45 (c,d) catalysts. The insets are Fast Fourier transform (FFT) images of square region (dot line). The $d$-spacing (nm) are calculated from FFT.

HRTEM images of Au-CeZr-15 and Au-CeZr-45 catalysts are presented in Figure $3 b, d$, respectively. There are some crystal planes of $\mathrm{CeO}_{2}$ (111) in Figure 3b, and no crystal planes of any $\mathrm{ZrO}_{2}$ species were observed. In contrast, both crystal planes of $\mathrm{CeO}_{2}$ (111) and $t-\mathrm{ZrO}_{2}$ (101) are presented in Figure $3 \mathrm{~d}$, suggesting that isolated $t-\mathrm{ZrO} 2$ located in $\mathrm{Au}-\mathrm{CeZr}-45$ catalyst, in good agreement with the calculated results from the above empirical formula and XRD. In addition, for the $\mathrm{CeO}_{2}$ (111) in Au-CeZr-15 catalyst, the $d$-spacing calculated from FFT using Digital Micrograph 3.7 software $(0.3105 \mathrm{~nm}$, Figure $3 b)$ and the Rietveld analysis of XRD patterns $(0.3115 \mathrm{~nm}$, Table 1$)$ are almost identical. The small error can be allowable because of the difference in calculation methods. However, there is a large difference in $d$-spacing of $\mathrm{CeO}_{2}$ (111) in Au-CeZr-45 catalyst calculated from FFT $(0.3135 \mathrm{~nm}$, Figure $3 \mathrm{~d})$ and the Rietveld analysis of XRD patterns $(0.3106 \mathrm{~nm}$, Table 1$)$. The $d$-spacing calculated from FFT $(0.3135 \mathrm{~nm}$, Figure $3 \mathrm{~d})$ is similar to the $d$-spacing of dopant-free Au-Ce catalyst $(0.3125 \mathrm{~nm}$, Table 1). The results illustrate that there is no solid solution in the rich-zirconia Au-CeZr-45 
catalyst because the excessive amount of zirconium led to the segregation of $\mathrm{Zr}$ from solid solution to form the isolated $t-\mathrm{ZrO}_{2}$ crystallites [30]. Thus, the $d$-spacing $(0.3106 \mathrm{~nm}$, Table 1$)$ is pseudo, because the XRD peaks consist of the overlapped diffraction peaks of fluorite $\mathrm{CeO}_{2}$ (JCPDS: 43-1002) and tetragonal $\mathrm{ZrO}_{2}$ (JCPDS: 24-1164), as shown in Figure 2b. Hereinto, there is no solid solution in the rich-zirconia Au-CeZr-45 catalyst, which will be further proven by the next Raman results.

For the Rietveld analysis of XRD patterns, the microstrain values were obtained (Figure 2d) to investigate the distortion of crystal lattice. It can be found that the microstrain of $\mathrm{CeO}_{2}$ monotonously increased with the increase of $\mathrm{Zr}$ content, and $\mathrm{CO}$ conversion at $250{ }^{\circ} \mathrm{C}$ has an excellent positive linear correlation with microstrain of $\mathrm{CeO}_{2}$. As stated in above paragraph, $\mathrm{Ce}-\mathrm{Zr}$-O solid solution was formed through the substitutional incorporation of $\mathrm{Zr}$ cations into $\mathrm{CeO}_{2}$ lattice, which led to the cell contraction (i.e., lattice distortion), embodying as the increase in microstrain. Our previous studies communicated that larger microstrain gave rise to stronger metal-support interactions and higher surface energy, as well as higher catalytic activities [32,33]. Therefore, the forming of Ce-Zr-O solid solution led to the lattice distortion (e.g., higher microstrain, smaller lattice spaces), stronger interaction between $\mathrm{Au}$ and $\mathrm{CeO}_{2}-\mathrm{ZrO}_{2}$ and higher surface energy, so as to improve catalytic activities of $\mathrm{Au}-\mathrm{CeO}_{2}-\mathrm{ZrO}_{2}$.

The structural studies of various $\mathrm{Au}-\mathrm{CeO}_{2}-\mathrm{ZrO}_{2}$ catalysts are also complemented by Raman results, as presented in Figure 4. The Raman spectra show a strong peak at about $460 \mathrm{~cm}^{-1}$ in all cases except Au-CeZr- 45 catalyst, which corresponds to the triply degenerate $\mathrm{F}_{2 \mathrm{~g}}$ mode and can be viewed as a symmetric breathing mode of $\mathrm{Ce}-\mathrm{O}$ [33]. For the $\mathrm{F}_{2 \mathrm{~g}}$ mode, the Raman bands shift to higher wavenumber with the increase of $\mathrm{ZrO}_{2}$ content (0-15 wt. \%), as shown in Figure $4 \mathrm{~b}$. Impressively, $\mathrm{CO}$ conversion at $250{ }^{\circ} \mathrm{C}$ correlates almost in a positive linear fashion with the $\mathrm{F}_{2 \mathrm{~g}}$ mode Raman shift of $\mathrm{Ce}-\mathrm{O}$ in $\mathrm{CeO}_{2}$, as presented in Figure 4c. The blue-shift of Raman bands at $460 \mathrm{~cm}^{-1}$ should be related to the introduction of $\mathrm{Zr}$, which affects the polarizability of the symmetrical stretching mode of [Ce-O] vibrational unit, embodying as the increase of the microstrain of $\mathrm{CeO}_{2}$ [32,33]. Thus, the results of Raman blue-shift (Figure 4c) and enhanced microstrain (Figure 2d) are consistent with each other.
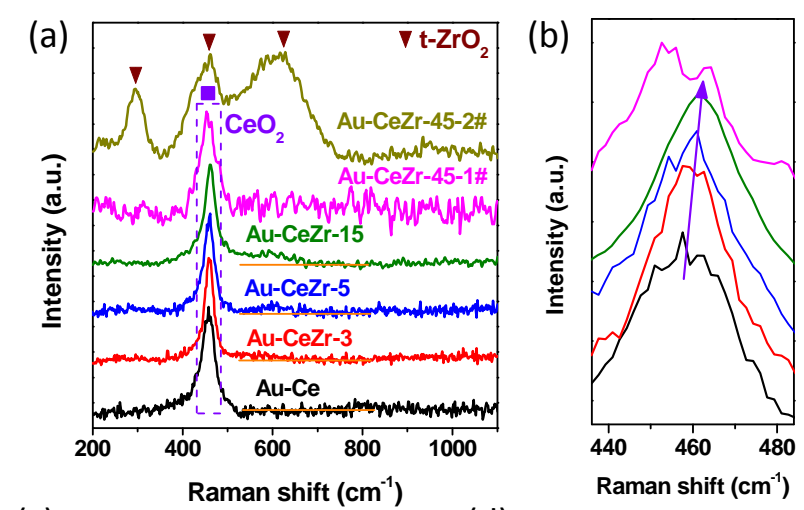

(c)

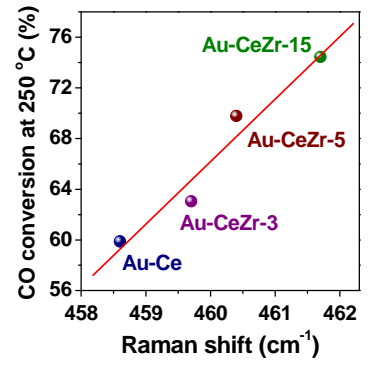

(d)

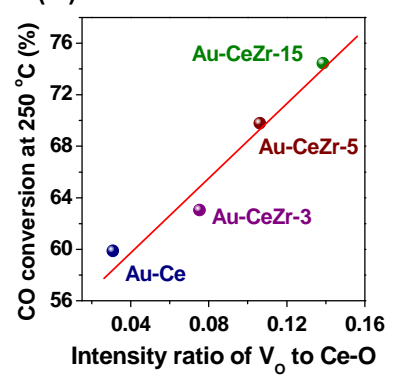

Figure 4. (a) Raman spectra of various $\mathrm{Au}-\mathrm{CeO}_{2}-\mathrm{ZrO}_{2}$ catalysts; (b) Magnification of the region around $460 \mathrm{~cm}^{-1}$ (the dotted rectangle in (a)); $\mathrm{CO}$ conversion at $250{ }^{\circ} \mathrm{C}(\%)$ vs. Raman shift of $\mathrm{Ce}-\mathrm{O}$ (c) and the Raman intensity ratio of oxygen vacancies $\left(\mathrm{V}_{\mathrm{o}}\right)$ to $\mathrm{Ce}-\mathrm{O}(\mathbf{d})$. 
Raman shift $(\Delta v)$ is the wavenumber difference between Stokes scattered light $\left(v_{\mathrm{s}}\right)$ and incident light $\left(v_{0}\right)$. To explain these phenomena, the calculation of the Raman band is simplified by a physical model-harmonic oscillator. The wavenumber $(v)$ is expressed by Hooke's law as follows:

$$
v\left(\mathrm{~cm}^{-1}\right)=(k / \mu)^{1 / 2} / 2 \pi c
$$

where $c$ is the velocity of light, $k$ is the bond force constant, and $\mu$ is the reduced mass. On the basis of the equation, the blue-shift of Raman bands at $460 \mathrm{~cm}^{-1}$ should be ascribed to the increase of the Ce-O bond force constant $(k)$, which arises from the decrease of the length of Ce-O bond. It shall result in the decrease of cell parameters $a$ and $d$-spacing, in very good agreement with XRD Rietveld analysis results (Table 1) and HRTEM analysis results (Figure 3).

In addition, there are almost the same Raman bands in the different focus regions of all the samples. However, the Au-CeZr-45 catalyst shows two different sets of Raman bands in different focus regions, which are shown in the Au-CeZr-45-1\# and Au-CeZr-45-2\# of Figure 4a, respectively. The $\mathrm{F}_{2 \mathrm{~g}}$ mode Raman bands of Ce-O in Au-CeZr-45-1\# downshifts and is similar to that of dopant-free Au-Ce catalyst, indicating that there is no solid solution in the rich-zirconia Au-CeZr-45 catalyst, in good agreement with HRTEM analysis results. The bands of Au-CeZr-45-2\# should be assigned to tetragonal $\mathrm{ZrO}_{2}$ $\left(t-\mathrm{ZrO}_{2}\right)$, implying that a part of zirconium exists as isolated $t-\mathrm{ZrO}_{2}$ in Au-CeZr- 45 catalyst, consistent with the above XRD and HRTEM analyses results. Therefore, the isolated $t-\mathrm{ZrO}_{2}$ crystallites block the contact between $\mathrm{Au}$ and ceria, resulting in the agglomeration of gold clusters and, as a consequence, poor WGS activity of Au-CeZr-45 catalyst.

Furthermore, the Raman spectra also exhibit a weak band at around $600 \mathrm{~cm}^{-1}$, which has been related to the presence of oxygen vacancies $\left(\mathrm{V}_{\mathrm{o}}\right)$ [33]. With the increase of $\mathrm{Zr}$ content, the intensity ratio of $\mathrm{V}_{\mathrm{o}}\left(600 \mathrm{~cm}^{-1}\right)$ to Ce-O $\left(460 \mathrm{~cm}^{-1}\right)$ gradually increased. Impressively, as shown in Figure $4 \mathrm{~d}, \mathrm{CO}$ conversion at $250^{\circ} \mathrm{C}$ has an excellent positive linear correlation with the intensity ratio of $\mathrm{V}_{\mathrm{o}}$ to Ce-O. The results indicate that the amount of oxygen vacancies gradually increased with the increase of $\mathrm{Zr}$ content. Thus, a part of zirconium has incorporated into ceria lattice along with the formation of oxygen vacancies.

In a word, for the low $\mathrm{ZrO}_{2}$ content (0-15 wt. \%), the Ce-Zr-O solid solutions were formed through the substitutional incorporation of $\mathrm{Zr}$ cations into $\mathrm{CeO}_{2}$ lattice, because the radius of $\mathrm{Zr}^{4+}$ is smaller than that of $\mathrm{Ce}^{4+}$. As a consequence, cell parameters $a$ and $d$-spacing and lattice distortion embodying are reduced as the increase of microstrain and oxygen vacancies arise. Thus, the appropriate $\mathrm{ZrO}_{2}$ can improve the WGS activities of Au-Ce catalyst. Whereas, for the rich-zirconia sample, Au-CeZr-45 has some isolated $t-\mathrm{ZrO}_{2}$ and fluorite $\mathrm{CeO}_{2}$ instead of solid solution. The isolated $t-\mathrm{ZrO}_{2}$ crystallites block the contact between $\mathrm{Au}$ and $\mathrm{CeO}_{2}$, resulting in the agglomeration of gold clusters. Thus, the $\mathrm{Au}-\mathrm{CeZr}-45$ catalyst presents poor WGS activity.

\section{Conclusions}

The water-gas shift catalytic activities of $\mathrm{Au}-\mathrm{CeO}_{2}$ catalysts were improved by the appropriate doping of zirconia in the range from 0 to $15 \mathrm{wt}$. \%, whereas excessive amount of zirconia could lead to a significant negative effect on catalytic performance. Effects of $\mathrm{Zr}$ content on the structural properties of $\mathrm{Au}-\mathrm{CeO}_{2}-\mathrm{ZrO}_{2}$ catalysts were quantitatively analyzed in detail and related to their WGS catalytic activities. For the low $\mathrm{ZrO}_{2}$ content $(0-15 \mathrm{wt}$. \%), the $\mathrm{Ce}-\mathrm{Zr}-\mathrm{O}$ solid solutions were formed through the substitutional incorporation of $\mathrm{Zr}$ cations into $\mathrm{CeO}_{2}$ lattice, resulting in the contraction of cell parameters $a$ and $d$-spacing (i.e., lattice distortion) and the increase of microstrain and oxygen vacancies. Quantitatively, the enhanced WGS activities have good linear correlation with cell parameters $a$, microstrain, Raman shift and oxygen vacancies. However, for the rich-zirconia (45 wt. \%) sample, Au-CeZr-45 has some isolated $t-\mathrm{ZrO}_{2}$ and fluorite $\mathrm{CeO}_{2}$ instead of solid solution. The isolated $t-\mathrm{ZrO}_{2}$ crystallites block the contact between $\mathrm{Au}$ and $\mathrm{CeO}_{2}$, resulting in the agglomeration of gold clusters and, as a consequence, poor WGS activity of Au-CeZr-45 catalyst. It is clear that 
quantitative analyses of correlation between the structural properties and WGS activities will provide a fundamental understanding to design more efficient WGS catalysts in the future.

Author Contributions: L.S. and L.Z. conceived and designed the experiments; L.S. and L.L. performed the experiments and wrote the manuscript.

Funding: This research was financially supported by the National Natural Science Foundation of China (21503092) and the Natural Science Foundation of Zhejiang Province (LQ18B030006). This research received no external funding.

Conflicts of Interest: The authors declare no conflicts of interest.

\section{References}

1. Flytzani-Stephanopoulos, M. Gold atoms stabilized on various supports catalyze the water-gas shift reaction. Acc. Chem. Res. 2013, 47, 783-792. [CrossRef] [PubMed]

2. Hakeem, A.A.; Vásquez, R.S.; Rajendran, J.; Li, M.; Berger, R.J.; Delgado, J.J.; Kapteijn, F.; Makkee, M. The role of rhodium in the mechanism of the water-gas shift over zirconia supported iron oxide. J. Catal. 2014, 313, 34-45. [CrossRef]

3. Saw, E.T.; Oemar, U.; Ang, M.L.; Kus, H.; Kawi, S. High-temperature water gas shift reaction on $\mathrm{Ni}-\mathrm{Cu} / \mathrm{CeO} 2$ catalysts: Effect of ceria nanocrystal size on carboxylate formation. Catal. Sci. Technol. 2016, 6, 5336-5349. [CrossRef]

4. Yang, M.; Allard, L.F.; Flytzani-Stephanopoulos, M. Atomically dispersed Au- $(\mathrm{OH})_{\mathrm{X}}$ species bound on titania catalyze the low-temperature water-gas shift reaction. J. Am. Chem. Soc. 2013, 135, 3768-3771. [CrossRef] [PubMed]

5. Ma, Z.; Yin, H.; Dai, S. Performance of $\mathrm{Au} / \mathrm{M}_{\mathrm{x}} \mathrm{O}_{\mathrm{y}} / \mathrm{TiO}_{2}$ catalysts in water-gas shift reaction. Catal. Lett. 2010, 136, 83-91. [CrossRef]

6. Shekhar, M.; Wang, J.; Lee, W.-S.; Williams, W.D.; Kim, S.M.; Stach, E.A.; Miller, J.T.; Delgass, W.N.; Ribeiro, F.H. Size and support effects for the water-gas shift catalysis over gold nanoparticles supported on model $\mathrm{Al}_{2} \mathrm{O}_{3}$ and $\mathrm{TiO}_{2}$. J. Am. Chem. Soc. 2012, 134, 4700-4708. [CrossRef] [PubMed]

7. Pérez, P.; Soria, M.A.; Carabineiro, S.A.; Maldonado-Hódar, F.J.; Mendes, A.; Madeira, L.M. Application of $\mathrm{Au} / \mathrm{TiO}_{2}$ catalysts in the low-temperature water-gas shift reaction. Int. J. Hydrogen Energy 2016, 41, 4670-4681. [CrossRef]

8. Song, L.; Lu, Z.; Zhang, Y.; Su, Q.; Li, L. Hydrogen-etched $\mathrm{TiO}_{2-x}$ as efficient support of gold catalysts for water-gas shift reaction. Catalysts 2018, 8, 26. [CrossRef]

9. Li, L.; Zhan, Y.; Zheng, Q.; Zheng, Y.; Chen, C.; She, Y.; Lin, X.; Wei, K. Water-gas shift reaction over $\mathrm{CuO} / \mathrm{CeO}_{2}$ catalysts: Effect of the thermal stability and oxygen vacancies of $\mathrm{CeO}_{2}$ supports previously prepared by different methods. Catal. Lett. 2009, 130, 532-540. [CrossRef]

10. González-Castaño, M.; Ivanova, S.; Ioannides, T.; Centeno, M.; Odriozola, J. Deep insight into $\mathrm{Zr} / \mathrm{Fe}$ combination for successful Pt $/ \mathrm{CeO}_{2} / \mathrm{Al}_{2} \mathrm{O}_{3}$ WGS catalyst doping. Catal. Sci. Technol. 2017, 7, 1556-1564. [CrossRef]

11. Ren, Z.; Peng, F.; Li, J.; Liang, X.; Chen, B. Morphology-dependent properties of $\mathrm{Cu} / \mathrm{CeO}_{2}$ catalysts for the water-gas shift reaction. Catalysts 2017, 7, 48-59. [CrossRef]

12. He, Y.; Du, S.; Li, J.; Zhang, R.; Liang, X.; Chen, B. Mesoporous ceria-supported gold catalysts self-assembled from monodispersed ceria nanoparticles and nanocubes: A study of the crystal plane effect for the low-temperature water gas shift reaction. ChemCatChem 2017, 9, 4070-4082. [CrossRef]

13. Tibiletti, D.; Meunier, F.; Goguet, A.; Reid, D.; Burch, R.; Boaro, M.; Vicario, M.; Trovarelli, A. An investigation of possible mechanisms for the water-gas shift reaction over a $\mathrm{ZrO}_{2}$-supported Pt catalyst. J. Catal. 2006, 244, 183-191. [CrossRef]

14. Li, J.; Chen, J.; Song, W.; Liu, J.; Shen, W. Influence of zirconia crystal phase on the catalytic performance of $\mathrm{Au} / \mathrm{ZrO}_{2}$ catalysts for low-temperature water gas shift reaction. Appl. Catal. A-Gen. 2008, 334, 321-329. [CrossRef]

15. Menegazzo, F.; Pinna, F.; Signoretto, M.; Trevisan, V.; Boccuzzi, F.; Chiorino, A.; Manzoli, M. Highly dispersed gold on zirconia: Characterization and activity in low-temperature water gas shift tests. ChemSusChem 2008, 1, 320-326. [CrossRef] [PubMed] 
16. Zane, F.; Trevisan, V.; Pinna, F.; Signoretto, M.; Menegazzo, F. Investigation on gold dispersion of $\mathrm{Au} / \mathrm{ZrO} 2$ catalysts and activity in the low-temperature WGS reaction. Appl. Catal. B-Environ. 2009, 89, 303-308. [CrossRef]

17. Xie, H.; Lu, J.; Shekhar, M.; Elam, J.W.; Delgass, W.N.; Ribeiro, F.H.; Weitz, E.; Poeppelmeier, K.R. Synthesis of Na-stabilized nonporous $\mathrm{t}-\mathrm{ZrO}_{2}$ supports and $\mathrm{Pt} / \mathrm{t}-\mathrm{ZrO}_{2}$ catalysts and application to water-gas-shift reaction. ACS Catal. 2013, 3, 61-73. [CrossRef]

18. Posada-Pérez, S.; Gutiérrez, R.A.; Zuo, Z.; Ramírez, P.J.; Viñes, F.; Liu, P.; Illas, F.; Rodriguez, J.A. Highly active $\mathrm{Au} / \delta-\mathrm{MoC}$ and $\mathrm{Au} / \beta-\mathrm{Mo}_{2} \mathrm{C}$ catalysts for the low-temperature water gas shift reaction: Effects of the carbide metal/carbon ratio on the catalyst performance. Catal. Sci. Technol. 2017, 7, 5332-5342. [CrossRef]

19. Lin, J.; Wang, A.; Qiao, B.; Liu, X.; Yang, X.; Wang, X.; Liang, J.; Li, J.; Liu, J.; Zhang, T. Remarkable performance of $\operatorname{Ir}_{1} / \mathrm{FeO}_{x}$ single-atom catalyst in water gas shift reaction. J. Am. Chem. Soc. 2013, 135, 15314-15317. [CrossRef] [PubMed]

20. Dufour, J.; Martos, C.; Ruiz, A.; Ayuela, F. Effect of the precursor on the activity of high temperature water gas shift catalysts. Int. J. Hydrogen Energy 2013, 38, 7647-7653. [CrossRef]

21. Shi, J.; Mahr, C.; Murshed, M.M.; Zielasek, V.; Rosenauer, A.; Gesing, T.M.; Bäumer, M.; Wittstock, A. A versatile sol-gel coating for mixed oxides on nanoporous gold and their application in the water gas shift reaction. Catal. Sci. Technol. 2016, 6, 5311-5319. [CrossRef]

22. Silva, L.P.; Terra, L.E.; Coutinho, A.C.; Passos, F.B. Sour water-gas shift reaction over Pt $/ \mathrm{CeZrO}_{2}$ catalysts. J. Catal. 2016, 341, 1-12. [CrossRef]

23. Daly, H.; Goguet, A.; Hardacre, C.; Meunier, F.; Pilasombat, R.; Thompsett, D. The effect of reaction conditions on the stability of $\mathrm{Au} / \mathrm{CeZrO}_{4}$ catalysts in the low-temperature water-gas shift reaction. J. Catal. 2010, 273, 257-265. [CrossRef]

24. Carter, J.H.; Liu, X.; He, Q.; Althahban, S.; Nowicka, E.; Freakley, S.J.; Niu, L.; Morgan, D.J.; Li, Y.; Niemantsverdriet, J. Activation and deactivation of Gold/Ceria-Zirconia in the low-temperature water-gas shift reaction. Angew. Chem. Int. Ed. 2017, 56, 16037-16041. [CrossRef] [PubMed]

25. Shim, J.O.; Hong, Y.J.; Na, H.S.; Jang, W.J.; Kang, Y.C.; Roh, H.S. Highly active and stable Pt-loaded $\mathrm{Ce}_{0.75} \mathrm{Zr}_{0.25} \mathrm{O}_{2}$ yolk-shell catalyst for water-gas shift reaction. ACS Appl. Mater. Interfaces 2016, 8, 17239-17244. [CrossRef] [PubMed]

26. Jeong, D.-W.; Na, H.-S.; Shim, J.-O.; Jang, W.-J.; Roh, H.-S. A crucial role for the $\mathrm{CeO}_{2}-\mathrm{ZrO}_{2}$ support for the low temperature water gas shift reaction over $\mathrm{Cu}-\mathrm{CeO}_{2}-\mathrm{ZrO}_{2}$ catalysts. Catal. Sci. Technol. 2015, 5, 3706-3713. [CrossRef]

27. Liang, S.; Veser, G. Mixed lanthana/ceria nanorod-supported gold catalysts for water-gas-shift. Catal. Lett. 2012, 142, 936-945. [CrossRef]

28. Gamboa-Rosales, N.K.; Ayastuy, J.L.; Gutiérrez-Ortiz, M.A. Effect of $\mathrm{Au}$ in $\mathrm{Au}-\mathrm{Co}_{3} \mathrm{O}_{4} / \mathrm{CeO}_{2}$ catalyst during oxygen-enhanced water gas shift. Int. J. Hydrogen Energy 2016, 41, 19408-19417. [CrossRef]

29. Dobrosz-Gómez, I.; Kocemba, I.; Rynkowski, J.M. Au/Ce $e_{1-x} \mathrm{Zr}_{x} \mathrm{O}_{2}$ as effective catalysts for low-temperature CO oxidation. Appl. Catal. B-Environ. 2008, 83, 240-255. [CrossRef]

30. Pojanavaraphan, C.; Luengnaruemitchai, A.; Gulari, E. Effect of catalyst preparation on $\mathrm{Au} / \mathrm{Ce}_{1-x} \mathrm{Zr}_{x} \mathrm{O}_{2}$ and $\mathrm{Au}-\mathrm{Cu} / \mathrm{Ce}_{1-x} \mathrm{Zr}_{x} \mathrm{O}_{2}$ for steam reforming of methanol. Int. J. Hydrogen Energy 2013, 38, 1348-1362. [CrossRef]

31. Kim, D.J. Lattice parameters, ionic conductivities, and solubility limits in fluorite-structure $\mathrm{MO}_{2}$ oxide (M. $=\mathrm{Hf}^{4+}, \mathrm{Zr}^{4+}, \mathrm{Ce}^{4+}, \mathrm{Th}^{4+}, \mathrm{U}^{4+}$ ) solid solutions. J. Am. Ceram. Soc. 1989, 72, 1415-1421. [CrossRef]

32. Li, L.; Song, L.; Zhu, L.; Yan, Z.; Cao, X. Black $\mathrm{TiO}_{2-x}$ with stable surface oxygen vacancies as the support of efficient gold catalysts for water-gas shift reaction. Catal. Sci. Technol. 2018, 8, 1277-1287. [CrossRef]

33. Li, L.; Song, L.; Chen, C.; Zhang, Y.; Zhan, Y.; Lin, X.; Zheng, Q.; Wang, H.; Ma, H.; Ding, L. Modified precipitation processes and optimized copper content of $\mathrm{CuO}-\mathrm{CeO}_{2}$ catalysts for water-gas shift reaction. Int. J. Hydrogen Energy 2014, 39, 19570-19582. [CrossRef]

(C) 2018 by the authors. Licensee MDPI, Basel, Switzerland. This article is an open access article distributed under the terms and conditions of the Creative Commons Attribution (CC BY) license (http:/ / creativecommons.org/licenses/by/4.0/). 